\title{
Serum Fetuin-A Level in Patients With Ankylosing Spondylitis and its Relationship With Clinical Parameters
}

\author{
Ferhat GÖKMEN, ${ }^{1}$ Ayla AKBAL, ${ }^{1}$ Fahri GÜNEŞ, ${ }^{2}$ Hakan TÜRKÖN, ${ }^{3}$ Ahmet VURAL,${ }^{4}$ Emine BİNNETOĞLU, ${ }^{2}$ \\ Erkam KÖMÜRCÜ, ${ }^{5}$ Hacer ŞEN, ${ }^{2}$ Mehmet AŞIK, ${ }^{2}$ Erdem AKBAL ${ }^{2}$ \\ ${ }^{1}$ Department of Physical Medicine and Rehabilitation, Medical Faculty of Çanakkale Onsekiz Mart University, Çanakkale, Turkey \\ ${ }^{2}$ Department of Internal Medicine, Medical Faculty of Çanakkale Onsekiz Mart University, Çanakkale, Turkey \\ ${ }^{3}$ Department of Clinical Biochemistry, Medical Faculty of Çanakkale Onsekiz Mart University, Çanakkale, Turkey \\ ${ }^{4}$ Department of Microbiology, Medical Faculty of Çanakkale Onsekiz Mart University, Çanakkale, Turkey \\ ${ }^{5}$ Department of Orthopedics and Traumatology, Medical Faculty of Çanakkale Onsekiz Mart University, Çanakkale, Turkey
}

\begin{abstract}
Objectives: This study aims to investigate the association of serum fetuin-A levels with disease activation and clinical parameters in ankylosing spondylitis (AS) patients.

Patients and methods: Forty-seven AS patients (30 males, 17 females; mean age $39.7 \pm 11.1$ years; range 20 to 69 years) and 30 healthy controls (14 males, 16 females; mean age $42.0 \pm 11.5$ years; range 19 to 63 years) were included in the study. Erythrocyte sedimentation rate, C-reactive protein, Bath Ankylosing Spondylitis Disease Activity Index, Bath Ankylosing Spondylitis Functional Index, Bath Ankylosing Spondylitis Radiology Index, and Bath Ankylosing Spondylitis Metrology Index were used in the assessment of AS. Serum fetuin-A levels were measured using ELISA.

Results: Mean serum fetuin-A values in AS patients $(984 \pm 203 \mathrm{ng} / \mathrm{mL})$ were significantly lower compared to controls $(1156 \pm 218 \mathrm{ng} / \mathrm{mL})(p=0.001)$. While a statistically significant negative correlation was detected in AS patients between fetuin-A values and C-reactive protein $(p=0.009, r=-0.377)$, no significant correlation was detected between erythrocyte sedimentation rate, Bath Ankylosing Spondylitis Disease Activity Index, Bath Ankylosing Spondylitis Metrology Index, Bath Ankylosing Spondylitis Functional Index or Bath Ankylosing Spondylitis Radiology Index parameters and fetuin-A.

Conclusion: Serum fetuin-A levels in AS patients were lower than the control group. However, further research is required to establish the role of serum fetuin-A levels as a surrogate marker of disease activity.

Keywords: Acute phase reactants; ankylosing spondylitis; fetuin-A.
\end{abstract}

Ankylosing spondylitis (AS) is a chronic inflammatory disease of the axial skeleton of uncertain etiology characterized by backache and morning stiffness. ${ }^{1}$ Several acute phase proteins, particularly erythrocyte sedimentation rate (ESR) and C-reactive protein (CRP), are used in AS as markers of disease activity to detect prognosis and evaluate treatment response. ${ }^{2}$ These proteins are synthesized from the liver in response to cytokines that increase during inflammation. Another inflammation marker known as fetuin-A, which is largely secreted from the liver in adults, has recently been described. Fetuin-A protein has a molecular weight of $59 \mathrm{kD}$ and is present at a serum concentration of $0.5-1 \mathrm{~g} / \mathrm{L} .{ }^{3}$ Some authors have argued that fetuin-A is a negative acute phase protein. ${ }^{4}$ Since serum levels decrease together with albumin in acute inflammation, it is thought to be a negative acute phase reactant. ${ }^{4}$ Serum fetuin-A levels have been reported to decrease by $20-30 \%$ in diseases such as rheumatoid arthritis (RA), pancreatitis and 
chronic kidney failure. ${ }^{5-7}$ Previous studies have also reported fetuin-A to be inversely correlated with levels of the proinflammatory cytokines interleukin-1 $\beta$, interleukin- 6 , and tumor necrosis factor- $\alpha .{ }^{8,9}$ However, others claimed that fetuin- $A$ is a positive acute phase reactant although this hypothesis was supported by only one study. That study demonstrated that fetuin-A levels were elevated in AS patients. ${ }^{10}$ It is therefore unclear whether fetuin- $A$ is a negative or positive acute phase reactant.

In this study, we aimed to investigate the association of serum fetuin-A levels with disease activation and clinical parameters in AS patients.

\section{PATIENTS AND METHODS}

This study was carried out at the Canakkale Onsekiz Mart University Medical Faculty Hospital between June 2013 and February 2014. Fortyseven AS patients (30 males, 17 females; mean age $39.7 \pm 11.1$ years; range 20 to 69 years) who were under observation and 30 controls (14 males, 16 females; mean age $42.0 \pm 11.5$ years; range 19 to 63 years) were included. Patients were asked about their age, sex, duration of disease, cigarette and alcohol consumption and any drugs they were still using. Patients with diabetes, hypertension, hyperlipidemia, chronic kidney disease, or chronic liver disease were excluded. The study was approved by Çanakkale Onsekiz Mart University Medical Faculty Hospital ethical committee and written consents were obtained from all patients.

Patients were evaluated with Bath Ankylosing Spondylitis Disease Activity Index (BASDAI), ${ }^{11}$ Bath Ankylosing Spondylitis Functional Index (BASFI), ${ }^{12}$ Bath Ankylosing Spondylitis Radiology Index (BASRI), ${ }^{13}$ and Bath Ankylosing Spondylitis Metrology Index (BASMI). ${ }^{14}$

Venous blood specimens were collected between 08:00 and 09:00 hours after 12-hour fasting and placed into vacuum tubes to detect fetuin-A levels in the patient and control groups. After specimens were kept for 30 minutes at room temperature, sera were separated by centrifugation at 4000 rpm for 10 minutes and then stored at $-80{ }^{\circ} \mathrm{C}$ until the day of the study. Fetuin-A levels in serum were measured using a commercial kit based on the quantitative sandwich ELISA technique (Catalog No. EK0757, Boster Biological Technology Co. Ltd., China). Results were read on an ELX 808 IU model ELISA reader.

\section{Statistical analysis}

Data analysis was performed with SPSS for Windows version 15.0 software program (SPSS Inc., Chicago, IL, USA). Variable conformity with normal distribution was investigated using the Kolmogorov-Smirnov/Shapiro-Wilk tests. Mean, standard deviation, median, minimum, maximum, frequency and percentage values were used to express descriptive data. The Student's t test was used to compare normally distributed variables between groups, and the Mann-Whitney $\mathrm{U}$ test for non-normally distributed variables. Chi-square test was used for comparison of the categorical variables. Correlations between constant variables in the patient group were examined using Spearman's correlation test. Significance was set at $p<0.05$.

\section{RESULTS}

There was no significant difference between the patient and control groups in terms of age, sex, body mass index, and alcohol or cigarette use (p>0.05, Table 1).

Mean duration of disease among AS patients was $5.4 \pm 7.3$ years. Forty-three patients were using nonsteroidal anti-inflammatory drugs and four patients were receiving anti-tumor necrosis factor therapy. Patients' mean BASDAI, BASFI, BASMI, BASRI-spine and total BASRI values were $3.2 \pm 1.8,2.7 \pm 2,3.7 \pm 1.9,4 \pm 1.5$ and $3.3 \pm 1.8$, respectively. Mean ESR and CRP values in AS patients were statistically higher than the control group ( $\mathrm{p}<0.001$, Table 1$)$.

Mean serum fetuin-A concentration in AS patients was significantly lower than the control group ( $p=0.001$, Figure 1). Mean fetuin-A value in AS patient group was $984 \pm 203 \mathrm{ng} / \mathrm{mL}$ compared to $1156 \pm 218 \mathrm{ng} / \mathrm{mL}$ in the control group. We observed a negative correlation between fetuin- $A$ and CRP ( $r=-0.377, p=0.009)$, but there was no significant correlation between fetuin-A and ESR, BASDAI, BASMI, BASFI or BASRI. 


\begin{tabular}{|c|c|c|c|c|c|c|c|}
\hline \multirow[t]{2}{*}{ Variables } & \multicolumn{3}{|c|}{ Patients $(n=47)$} & \multicolumn{3}{|c|}{ Controls $(n=30)$} & \multirow[b]{2}{*}{$p$} \\
\hline & $\mathrm{n}$ & $\%$ & Mean \pm SD & $\mathrm{n}$ & $\%$ & Mean \pm SD & \\
\hline Age (years) & & & $39.7 \pm 11.1$ & & & $42 \pm 11.5$ & 0.380 \\
\hline Sex & & & & & & & 0.138 \\
\hline Female & 17 & & & 16 & & & \\
\hline Male & 30 & & & 14 & & & \\
\hline Body mass index $\left(\mathrm{kg} / \mathrm{m}^{2}\right)$ & & & $27.3 \pm 5.4$ & & & $28.8 \pm 4.3$ & 0.220 \\
\hline Cigarette use & & 44.7 & & & 50 & & 0.558 \\
\hline Alcohol use & & 25.5 & & & 15 & & 0.545 \\
\hline Erythrocyte sedimentation rate (mm/hour) & & & $30.7 \pm 19.71$ & & & $10.6 \pm 7.7$ & $<0.001$ \\
\hline C-reactive protein (mg/dL) & & & $1.17 \pm 1.16$ & & & $0.28 \pm 0.24$ & $<0.001$ \\
\hline Fetuin-A (ng/mL) & & & $984 \pm 203$ & & & $1156 \pm 218$ & 0.001 \\
\hline
\end{tabular}

\section{DISCUSSION}

Fetuin-A behaves as a negative acute phase reactant, the levels of which decrease in acute and chronic inflammation. Lebreton et al. ${ }^{4}$ showed that fetuin-A concentrations decrease throughout inflammation and trauma. Furthermore, their results showed that fetuin- $A$ had a negative correlation with acute-phase reactants alpha 1 antitrypsin and haptoglobin and a positive correlation with albumin. These findings indicate that fetuin- $A$ is a negative acute-phase reactant. In a study on peritoneal dialysis patients, Wang et al. ${ }^{15}$ demonstrated a reverse correlation between fetuin-A and inflammation and malnutrition. Serum fetuin-A was highest among patients without inflammation and malnutrition and lowest among those with both inflammation and malnutrition. In a study of patients with chronic kidney failure, Oikawa et al. ${ }^{16}$ investigated levels of serum fetuin- $A$ in hemodialysis patients and showed them to be significantly lower than in healthy controls. Furthermore, they identified a negative correlation between serum fetuin- $A$ levels and high-sensitivity CRP and a positive association with serum albumin. These data suggest that low fetuin-A level is a useful predictor of inflammation.

There is limited number of studies in the literature concerning fetuin-A in inflammatory rheumatic diseases. Oncu et al. ${ }^{17}$ studied 67 familial Mediterranean fever (FMF) patients. The authors measured fetuin- $\mathrm{A}$ three times: during the attack-free period, 12 hours after an attack and seven days after an attack, and discovered significantly decreased fetuin-A compared to the twelve-hour attack period. In the same study, they also observed a significant negative correlation between fetuin-A and ESR, CRP, cerulopasmin, fibrinogen, and white blood cell count. The results of this study indicate that fetuin-A can be a novel indicator of disease activity in FMF patients and used as an additional marker to differentiate FMF attacks.

Sato et al. ${ }^{5}$ studied 102 RA patients and a 155-member control group and reported low fetuin-A in RA patients. Fetuin-A was negatively correlated with ESR and CRP, while a positive correlation was identified with albumin, hemoglobin and total cholesterol. However, no association was shown between fetuin-A and age, sex, serum creatinine levels, calcium levels

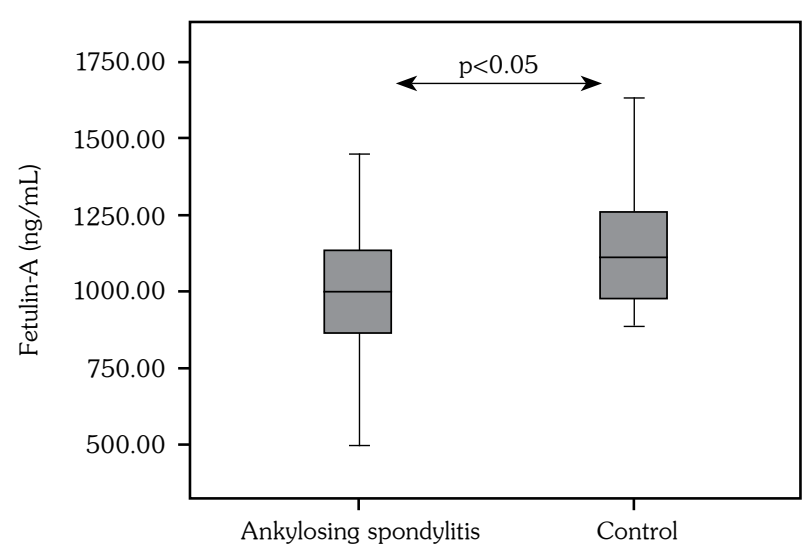

Figure 1. Comparison of fetuin- $A(n g / m L)$ levels in patients with ankylosing spondylitis and control subjects. 
or aortic calcification. Similarly, in a study of 35 RA patients and 30 healthy controls, Saroha et al. $^{18}$ reported lower serum fetuin-A levels in patients compared to controls. They concluded that the low serum fetuin-A concentrations in RA patients might be due to chronic inflammation developing in association with malnutrition and inflammatory activity. ${ }^{5}$ However, no correlation was detected with clinical parameters such as ESR, BASDAI, BASFI or BASMI. Additionally, in the same study, a comparison of fetuin-A levels of patients using biological agents with high disease activity score and peripheral joint involvement revealed no significant difference. Sar1 et al. ${ }^{10}$ suggested that the elevated fetuin-A might be attributed to the disease itself, independently of clinical markers. In our study, we detected lower serum fetuin-A levels in the AS patient group compared to the control group $(p=0.001)$. We also identified a negative correlation between patient fetuin-A levels and CRP. However, we found no correlation between fetuin- $A$ and disease markers such as ESR, BASDAI, BASFI or BASMI. In contrast to Sar1 et al., ${ }^{10}$ we also assessed patient BASRI indices. However, we did not detect any correlation between BASRI and fetuin-A. In contrast to previous studies reporting high fetuin-A levels in AS patients, ${ }^{10}$ we found low fetuin-A levels similar to studies in RA and FMF patients. ${ }^{5,17,18}$ In addition, the negative correlation we showed between CRP and fetuin-A, and the negative correlation with ESR and CRP demonstrated in studies involving chronic kidney failure, cardiovascular disease, and rheumatic diseases indicate that fetuin-A may be a negative acute phase reactant. ${ }^{5,16-19}$

In conclusion, we demonstrated that fetuin-A levels in AS patients were lower than in control subjects. We also showed that fetuin-A is negatively correlated with CRP. We suggest that fetuin-A in AS patients may be a novel indicator of disease activity. Furthermore, the negative correlation between fetuin-A and CRP may be indicative of an inflammation related decrease of fetuin- $A$ in patients with AS.

\section{Declaration of conflicting interests}

The authors declared no conflicts of interest with respect to the authorship and/or publication of this article.

\section{Funding}

The authors received no financial support for the research and/or authorship of this article.

\section{REFERENCES}

1. Braun J, Sieper J. Ankylosing spondylitis. Lancet 2007;369:1379-90.

2. Dougados M, Gueguen A, Nakache JP, Velicitat P, Zeidler H, Veys E, et al. Clinical relevance of C-reactive protein in axial involvement of ankylosing spondylitis. J Rheumatol 1999;26:971-4.

3. Heiss A, DuChesne A, Denecke B, Grötzinger J, Yamamoto K, Renné T, et al. Structural basis of calcification inhibition by alpha 2-HS glycoprotein/ fetuin-A. Formation of colloidal calciprotein particles. J Biol Chem 2003;278:13333-41.

4. Lebreton JP, Joisel F, Raoult JP, Lannuzel B, Rogez JP, Humbert G. Serum concentration of human alpha 2 HS glycoprotein during the inflammatory process: evidence that alpha $2 \mathrm{HS}$ glycoprotein is a negative acute-phase reactant. J Clin Invest 1979;64:1118-29.

5. Sato H, Kazama JJ, Wada Y, Kuroda T, Narita I, Gejyo F, et al. Decreased levels of circulating alpha2Heremans-Schmid glycoprotein/Fetuin-A (AHSG) in patients with rheumatoid arthritis. Intern Med 2007;46:1685-91.

6. Kusnierz-Cabala B, Gurda-Duda A, Panek J, Fedak D, Dumnicka P, Solnica B, et al. Serum fetuin A concentrations in patients with acute pancreatitis. Clin Lab 2010;56:191-5

7. Metry G, Stenvinkel P, Qureshi AR, Carrero JJ, Yilmaz MI, Bárány $P$, et al. Low serum fetuin-A concentration predicts poor outcome only in the presence of inflammation in prevalent haemodialysis patients. Eur J Clin Invest 2008;38:804-11.

8. Kelly RA, Smith TW. Cytokines and cardiac contractile function. Circulation 1997;95:778-81.

9. Li W, Zhu S, Li J, Huang Y, Zhou R, Fan X, et al. $A$ hepatic protein, fetuin- $A$, occupies a protective role in lethal systemic inflammation. PLoS One 2011;6:16945.

10. Sari I, Kebapcilar L, Taylan A, Bilgir O, Kozaci DL, Yildiz Y, et al. Fetuin-A and interleukin-18 levels in ankylosing spondylitis. Int $\mathrm{J}$ Rheum $\mathrm{Dis}$ 2010;13:75-81.

11. Garrett S, Jenkinson T, Kennedy LG, Whitelock H, Gaisford P, Calin A. A new approach to defining disease status in ankylosing spondylitis: the Bath Ankylosing Spondylitis Disease Activity Index. J Rheumatol 1994;21:2286-91.

12. Calin A, Garrett S, Whitelock H, Kennedy LG, O'Hea J, Mallorie P, et al. A new approach to defining functional ability in ankylosing spondylitis: the development of the Bath Ankylosing Spondylitis Functional Index. J Rheumatol 1994;21:2281-5. 
13. MacKay K, Mack C, Brophy S, Calin A. The Bath Ankylosing Spondylitis Radiology Index (BASRI): a new, validated approach to disease assessment. Arthritis Rheum 1998;41:2263-70.

14. Jenkinson TR, Mallorie PA, Whitelock HC, Kennedy LG, Garrett SL, Calin A. Defining spinal mobility in ankylosing spondylitis (AS). The Bath AS Metrology Index. J Rheumatol 1994;21:1694-8.

15. Wang AY, Woo J, Lam CW, Wang M, Chan IH, Gao P, et al. Associations of serum fetuin-A with malnutrition, inflammation, atherosclerosis and valvular calcification syndrome and outcome in peritoneal dialysis patients. Nephrol Dial Transplant 2005;20:1676-85.

16. Oikawa O, Higuchi T, Yamazaki T, Yamamoto C, Fukuda N, Matsumoto K. Evaluation of serum fetuin-A relationships with biochemical parameters in patients on hemodialysis. Clin Exp Nephrol 2007;11:304-8.

17. Oncu K, Yazgan Y, Tanoglu A, Kaplan M, Ermis F, Ipcioglu OM, et al. Can serum fetuin-A be regarded as an inflammatory marker among patients with familial Mediterranean fever? Dig Dis Sci 2013;58:3212-7.

18. Saroha A, Kumar S, Chatterjee BP, Das HR. Jacalin bound plasma O-glycoproteome and reduced sialylation of alpha 2-HS glycoprotein (A2HSG) in rheumatoid arthritis patients. PLoS One 2012;7:e46374

19. Bilgir O, Kebapcilar L, Bilgir F, Bozkaya G, Yildiz Y, Pinar $P$, et al. Decreased serum fetuin-A levels are associated with coronary artery diseases. Intern Med 2010;49:1281-5. 